\title{
Teaching English Vocabulary by Using Last One Standing Game at the Third Grade Students of SMP Tamalate Makasar
}

\author{
M. Dahlan Bahang, Iriany Kusuma Wijaya and Juniati Banne Karua \\ English Education of STKIP - YPUP Makassar, South Sulawesi, Indonesia
}

How to cite this paper: Bahang M.D., Wijaya I.K., Karua J.B.(2019). Teaching English Vocabulary by Using Last One Standing Game at the Third Grade Students of SMP Tamalate Makasar. The Educational Review, USA, 3(10), 135-141.

http://dx.doi.org/10.26855/er.2019.10.002

*Corresponding author: M. Dahlan Bahang, English Education of STKIP - YPUP Makassar, South Sulawesi, Indonesia.

Email: mdahlan.hbahang@gmail.com

\begin{abstract}
The objective of this research is to find out the use of Last One Standing Game in improving the students' vocabulary mastery at the third grade students of SMP Tamalatea Makassar. In this research, the researcher uses pre-experimental method. The total sample was 18 students and it used total sampling technique. The result showed that the students' mean score in pretest was 24.17 and the students' mean score in posttest was 77.22. It means that the students' mean score in posttest was higher than the students' mean score in pretest. Based on the data above, the researcher concludes that the use of Last One Standing Game can improve the students' vocabulary mastery of SMP Tamalatea Makassar.
\end{abstract}

Keywords

Last One Standing, Vocabulary Mastery

\section{Introduction}

Language is a system of communication consists of sounds, words, and grammar or the system of communication used by the people of the particular country of the profession (Cambridge Advanced Learner's Dictionary). Language is an important part of human life. People use language in any field in their daily activity. But every country has a different language, so if they want to make a communication with a different country they should use that same language, that language is called international language.

Everybody knows that English is an international language and has been very popular as an important language. Now we can see that English cannot be separated from human life around the world. English is used almost in all aspects of our daily activities such as technology, trades, economics, politics, and language and literature of culture.

In Indonesia, English has been taught as the first foreign language that should be learned and understood, because almost all of science and technology are written in English. The Indonesian government decides English as the first foreign language, which must be taught from junior high school up to university even English is started to be taught for elementary students as the local content.

There are four language skills namely listening, speaking, writing and reading. To achieve the four skills, it is important to master language components namely vocabulary, grammar, and pronunciation. One of the language components that holds an important role is vocabulary. We can see that in speaking skills, the student cannot speak English because they have limited vocabulary. In reading and listening skills, the student cannot understand what they read and listen, because they are lack of vocabulary.

So, vocabulary is one of the important things in learning English. Learning vocabulary for young learner is fundamental because the ability of the students to learn English especially to read as well as to comprehend the subject is determined by vocabulary competence if the learners have no or lack vocabulary and the ability to communicate and to convey they 
need could not be established.

Based on the pre-observation on $7^{\text {th }}$ August 2018 of Magang III in SMP Tamalatea Makassar especially to the second grade students, the researcher found the students were still lacking of vocabulary.There were some problems that made the students lack of vocabulary. The first, the students did not had the motivation to study. The second, the students were less interested in the English class. The third, the students got difficulties to pronounce vocabulary correctly and the last, the students have difficulty in remembering the meaning of the word.

Based on the problem above, the English teacher must have a challenging task to find ways to motivate students to learn English. Teaching vocabulary has been presented in so many methods and techniques, and must be taught in various ways so that the students can be interested in learning it.

One of the strategies in improving the students' vocabulary is to play games. Playing games is a good way in teaching vocabulary. This is not a new method. It has been around and used for a long time. Playing games is considered very effective and teachers indirectly add an element of pleasure or relaxation in vocabulary practices. The aim is to make the material more interesting, fun, and challenging and especially to introduce new vocabulary.

One of games that will be practiced here was Last One Standing game. Last One Standing game was a kind of mentioning word which a person who can stand up until the end of the game was the winner. This game will be applied to the third grade students to improve their vocabulary in learning English because they have fun and relax.

Based on the explanation above, the researcher was interested in conducting a research under the title "Teaching English Vocabulary by Using Last One Standing Game at the Third Grade Students of SMP Tamalatea Makassar".

\subsection{Problem Statement}

Based on the background above, the researcher stated that the problem statement of this research was "Does last one standing game improve the students' vocabulary at the third gradestudentsof SMP Tamalatea Makassar?"

The objective of the research was to find out whether Last One Standing Game improves the students' vocabulary at the third grade students of SMP Tamalatea Makassar.

The result of the research was expected to be useful information in teaching and learning English at junior high school, especially to the third grade students of SMP Tamalatea Makassar and to show the teacher awareness of the importance of using Last One Standing Game.

The scope of the research was restricted to the teaching vocabulary at the third grade students ofSMP Tamalatea Makassar to improve students' vocabulary. The researcher will focus on improving students' vocabulary by using last one standing game especially in compound noun and compound adjective.

\section{Review of Related Literature}

Many studies have been performed by the research related to the use of strategies, approaches, or media, in motivating the learner to learn English vocabulary. Some of them were mentioned with their reported as follows:

Esti (2014) stated "the use of last one standing game as techique in teaching English vocabulary for the fifth grade students is good to improve students' vocabulary mastery". It is make the students felt enjoy and increase students' motivation in learning English.

Dhiastri (2015) stated "using last one standing game is effective to teach English vocabulary for the students in elementary level".

Rohmah (2017) stated "using last man standing game is effective to enrich students' vocabulary mastery for the students in junior high school".

Based on the previous findings, the researcher concluded that there were many methods or techniques that can be used to improve vocabulary mastery of students especially using game in learning and teaching process.Beside the methods can make students easy to improve their vocabulary.

\subsection{Some Pertinent Ideas}

Vocabulary is one of language components that is really essential in language learning and teaching process. Pusat 
Dunia Ilmu (2011) stated "vocabulary is an important aspect in a language. To master a language, a learner should master the vocabulary of the language. In other word, the learner cannot use a language without having knowledge about vocabulary of that language."

Nugroho and Suprapto (2017) stated"vocabulary is one of the basic things in learning English". We cannot say anything without vocabulary. What can we say without vocabulary? Even a word can express our feelings. For example, when we say "Amazing" it's only one word, but you can express that you feel amazed by using it.

From the definitions above, it can be concluded that vocabulary is the total number of words that are needed to communicate ideas and express the speakers' meaning. That is the reason why it is important to learn vocabulary.

According to Bhasin (2012), vocabulary is very important for correct and effective communication. There are many ways to improve your vocabulary. When working to improve your vocabulary it's important to set your targets and to choosen the best way in which you want to learn to increase your vocabulary. Reading can be a great way to improve your vocabulary.

Last one standing game is a kind of mentioning word which a person who can stand up until the end of the game is the winner.

Bakhsh (2016) stated"Last one standing, where a topic is given to the children e.g. fruit. They have to stand up in a circle and the teacher count to three and give out the topic. After that, the first student in the circle will have to give a word related to the topic and so on. The students who can not say a new word or repeat the words of the last student has to take a seat. The last student standing will get the point".

\section{a. The advatages of last one standing game}

The advantages of using last one standing game in the classroom:

1) Last one standing game is fun.

2) It can give more motivation while learning how to play the game.

3) It can help the students remember some vocabularies that is difficult to memorize.

4) It can invite students to think fast.

5) It can influence the students to be more creative and active.

\section{b. Procedure of teaching vocabulary by using last one standing game.}

Teacher is to keep going until only one person left, they are the winner.

\section{Method of the the Researce}

In this research, the researcher used pre-experimental method with one group pre-test, post-test design. It aimed to find out the students' vocabulary by using Last One Standing game in teaching vocabulary to the third grade students of SMP Tamalatea Makassar. The success of the treatment was determined by compaining the pretest and posttest score.

The design was illustrated below:

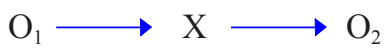

Where:

$$
\begin{aligned}
& \mathrm{O}_{1}=\text { Pre-test } \\
& \mathrm{X}=\text { Treatment } \\
& \mathrm{O}_{2}=\text { Post-test }
\end{aligned}
$$

(Jhonson \& Christensen: 2014)

There are two research variables in this research namely independent variable and dependent variable. Independent variable was the use of last standing game in teaching and learning vocabulary and dependent variable was the students' vocabulary development.

The population of this research was the third grade students of SMP Tamalatea Makassa rand the total number of 
population was 18 students.

In this research, the researcher used total sampling technique. The sample was the third grade students of SMP Tamalatea Makassar and the total sampel was 18 students.

The instrument of the research was missing word in pretest and posttest. The purpose of pretest was to know how far students' vocabulary before using last one standing game and the purpose of posttest was to know the improvement of students' vocabulary after using last one standing game.

In collecting the data the researcher used 20 questions missing words. The test was done to know the students vocabulary ability in pre-test and post-test. The pre-test was intended to find the students' prior knowledge in English vocabulary while the post-test was intended to find the students' vocabulary skill after the treatment using last one standing game.

\section{Findings and Discussion}

The findings deal with the description of scoring classification of the students' pretest and posttest of pre-experimental based on the English vocabulary scoring classification, the mean score, standard deviation, t-test value and hypothesis used with formula. The data of finding was analyzed into mean score formula. T-test formula was applied to analyze significant difference between the data of pretest and posttest. These findings were elaborated below.

The findings of the research deals with the students' score of pretest and posttest, the frequency and rate precentage of the students' score, the mean score, total score, and hypothesis testing.

For the first meeting, the researcher gave pretest before giving treatmentto know how far their English vocabulary. The pretest consisted of 20 questions in missing word. Those questions consisted of compound noun and compound adjective.

The students' score in pretest were clearly explained that most of the students classified as very poor score. So, it can be said students' vocabulary mastery were still low.

The result shows the categories of the students' score based on the classification score and illustrated the rate percentage and frequency of the students' pretest. Based on the result, the students result of pretest can be concluded that most of the students got $83,33 \%$.

For the second meeting until the fourth meeting, the researcher gave the treatment before giving posttest to help them in improving their vocabulary by using last one standing game. In treatment, the researcher explained the material about compound noun and compound adjective, and then the researcher divided the students into two groups. The procedures of the treatment from the first day up to the fourth day were similar.

The students understood the explaination easily because the game was simple for them. Then, the researcher divided the students into two groups, each group consisted of nine students. The researcher form of two session, the first session played by the first group and the second session played by the second group. And the researcher introducing the new vocabulary and making the students know how to pronounce correctly by repetition and echoing. And the researcher asked the students to stand up. The researcher explained to them that when I count 123 and point at them, they must say one of the vocabulary words of their choose. The researcher also explained that is it important that they respond quickly as if they take too long they will be out. And then the researcher explained that you will be saying one of the vocab words at the same word then they are out and must sit down. The researcher was to keep going until only one person left, he/she is the winner. And the winner of each session got a appreciation. After that, the researcher asked the students to write down all of the vocabulary which have been mentioned in the game.

To quantify the students understanding and the effectiveness of this strategy, the researcher prepared the second test. The researcher gave the posttest after the researcher delivered the treatments. It aimed to find out the students' vocabulary achievement after the students have been learned vocabulary by Last One Standing Game. In this test, the researcher intended to know the result value after doing the treatment. It was expected students' posttest result was better than pretest result, because the researcher had already given the material by using Last One Standing Game in teaching. In this test, the researcher found that the students looked easily in answering the questions given. It was known by the facial expression of the students and they look so relax and enjoy during finishing the test. They worked on the posttest so quickly and they had collected their answer before the due time. Absolutely, the posttest result of the students was improved. 
The result of posttest shows that most of the students in class IX of SMP Tamalatea Makassar got good score. The researcher could find that there were nine students got 80 score. The students' score in posttest were better than the score in pretest.

Based on the posttest score, the researcher can identify that the application of teaching material by using Last One Standing Game within four meetings has succeeded to change the students' very poor score in pretest into good in posttest. It means that there was a significant difference before and after teaching vocabulary by using Last One Standing Game.

The result shows $50 \%$ of the students classified into good score. It can be said that the rate percentage in the posttest was greater than the rate percentage in pretest.

The mean score of the students' pretest with the total 24,17 which classified as very poor while the mean score of the students' posttest with the total 77,22 which classified as good. It indicates that the everage score of the students' posttest was higher than the everage score of the students' pretest.

The result shows that $t$-test was higher that t-table value $(12,31>2,110)$. It can be concluded that there was a significant difference between the result of the students' pretest and posttest after using Last One Standing Game in teaching vocabulary.

Comparing with the test value, it can be concluded that $t$-test value $(12,31)$ was higher than $t$-table $(2,110)$. In other hand we said that $12,31>2,110$. It concludes $\left(\mathrm{H}_{0}\right)$ of this research is rejected and $\left(\mathrm{H}_{1}\right)$ is acceptable because there is a significant difference between the pretest and posttest result by using 'Last One Standing Game' for improving students' vocabulary.

From the analysis above, the researcher concludes that there was a significant difference between the result of the pretest and posttest of the students' score after using Last One Standing Game in students' vocabulary mastery at the third grade students of SMP Tamalatea Makassar.

The result showed the t-test $(12,31)$ was better than $t$-table $(2,110)$. So, there was a significant difference of the students' pretest and posttest.

In this part, the researcher discussed the result by using "Last One Standing Game" to improve students' vocabulary mastery. The application of Last One Standing Game at the third grade students of SMP Tamalatea Makassar could improve the vocabulary mastery of students.

To know the effect of Last One Standing Game strategy of students English vocabulary, the researcher administrated the pretest, did the treatment after having pretest, and did posttest.

The discussion deals with interpretation of the findings derived from the data analysis, the description of the data collected through vocabulary test which explained in the previous part which showed that the students' vocabulary achievement was developed. It was supported by the result of frequency and rate percentage of the students' pretest and posttest. The students' score after presenting material by using Last One Standing Game strategy in teaching and learning vocabulary test was better than before the treatment was given to them.

From the discussion above, it indicates that the use of 'Last One Standing Game' was improved the students' vocabulary mastery at the third grade students of SMP Tamalate Makassar.

\section{Conclusion and Suggestion}

This chapter deals with the conclusion and the suggestion of this research.

Based on the result of the data analysis, research findings and discussion in the previous chapter, the research formulates the conclusion as follow:

The use of Last One Standing Game as treatment of the research was applied by teaching vocabulary. The mean score' pretest (before given the treatment) was 24,17 score which chould be categorized as very poor, while on the students' mean score in posttest (after given the treatment) was 77,22 which could be categorized as good. Thus, the application of treatment by using Last One Stranding Game in teaching and learning vocabulary could improve students' achievement from 24,17 to 77,22 score. It says the treatment has increased to the achievement of students' posttest score beacuse it was higher than the pretest scores. It is concluded that using Last One Standing Game can improve students' vocabulary at the Third Grade Students of SMP Tamalatea Makassar. 
Teaching and learning English require more attention from both the students as the language learners and the future researcher as the language facilitators. As the language learners, the students should have high motivation in learning English. So, whatever the technique applied by the researrcher, they can understand it well. As the facilitators, the next researcher should provide the students some teaching teachniques which aid them to reach the goal of learning the language. The next researcher also must be able to be an educator not only in intelligence aspect, but also in emotional and spiritual aspect.

Related to English language teaching, Last One Standing Game has been proven to be an effective way of enhancing the language competence particularly vocabulary skill. The next researher have to be more creative in preparing and selecting materials to make the learning situation more interesting and motivating.

\section{The researcher would give some suggestions:}

1. For the students of English Education Department

The students of English Education Department have to develop the use of Last One Standing Game as a tecnique in teaching and learning vocabulary because it is more effective and efficient.

2. For other researchers

It needs an outgoing research because this research was only aimed at finding the significance of Last One Standing Game on vocabulary. This study focuses on improving vocabulary mastery through last one standing game at the third grade students of SMP Tamalatea Makassar. The researcher hopes that the finding of the study will be useful for the other researcher in the future researcher. However, this technique needs more development and considering with the situation at the future.

Finally, the researcher considers that this study still needs validation from the next researcher that has the same topic as this study.

\section{Bibliography}

Cristina, Cruz-Wiley. 2010. Vocabulary Strategies. Houston Independent School District. Hattie Mae White Educational Support Center. Website: www.houstonisd.org

Ery, Septiani Dhiastri. 2015. Last One Standing Game as the Technique to Teach Vocabulary Mastery of Fifth Grade Students of SDN Demaan Jepara in Academic Year 2015/2016. Skripsi. English Education Department, Teacher Training and Education Faculty, Maria Kudus University.

Hasanah, Siti Rohmah. 2017. The Effectiveness of the Last Man Standing Game to Enrich Students'Vocabulary Matery. (A Case of the Eight Greders f SMP Al-Fattah Semarang in the Academic Year of 2016/2017). Undergraduate thesis, Fakultas Bahasa UNISSULA.

Gay, L.R. 2012. Educational Research. Competencies for Analysis and Applications. Late of Florida International University.

Kevin, Flanigan. 2015. Building a Better Vocabulary. Course Guidebook. West Chester University of Pennsylvania. www.thegreatcourses.com

Oxford, Dictionary. 2018. Oxford Advanced Learner's Dictionary. Website: https://en. oxforddictionaries.com./ definition/vocabulary. Accessed 23 May 2019.

Pan Qi and Xu Runjiang. 2011. Vocabulary Teaching in English Language Teaching. Theory and Practice in Language Studies, Vol.1, No. 11. Pp. 1586-1589, November 2011.

Parker, Jason. 2011. Website: https://www.theibsc.org/uploaded/IBSC/Conference_and_workshops/2011_Workshops/ Handouts/Parker-Jason_Handout.pdf

Pusat Dunia Ilmu. 2011. Pundipusatduniailmu.blogspot.com/2011/10/vocabulary. html? m=1. Accessed 23 May 2019.

Rahmawati, Esti. 2014. Teaching English Vocabulary for Fifth Grade Students of MI Darul Falah Ngembal Kudus by Using Last One Standing Game in Academic Year 2013/2014. "Skripsi” of English Education Department, Teacher Training and Education Faculty of Muria Kudus. 
Rewa, Bhasin. 2012. Enhance Your Vocabulary. Website: www.diamondbook.in

R. Burke Jhonson and Larry Christensen. 2014. Educational Research. Quantitative, Qualitative, and Mixed Approaches. London| New Delhi| Singapore| Washington DC

Sahar, Ameer Bakhsh. 2016. Using Games as a Tool in Teaching Vocabulary to Young Learners. English Language Institute, King Abdul Aziz University, Jeddah, Saudi Arabia. URL: http://dx.doi.org/10.5539/elt.v9n7p120

Susan Hanson and Jennifer F.M. Padua. 2011. Teaching Vocabulary Explicitly. Pacific Resources for Education and Learning.www.prel.org 